\title{
The Effect of Pre-Service Teachers' Life Skills on Teacher Self-Efficacy
}

\author{
Bengisu Koyuncu ${ }^{1}$ \\ ${ }^{1}$ Department of Educational Science,Mimar Sinan Fine Arts University, Istanbul, Turkey \\ Correspondence: Bengisu Koyuncu, Department of Educational Science, Mimar Sinan Fine Arts University, \\ Istanbul, Turkey.
}

Received: June 19, 2018

Accepted: July 15, $2018 \quad$ Online Published: July 28, 2018

doi:10.5539/jel.v7n5p 188

URL: https://doi.org/10.5539/jel.v7n5p188

\begin{abstract}
The aim of this study is to find out the extent to which pre-service teachers' life skills predict their sense of self-efficacy. The study employed a relational screening model within the quantitative research paradigm and included 195 pre-service teachers in Mimar Sinan Fine Arts University Pedagogical Formation Program. The data was collected through a life skills scale, a teacher self-efficacy scale and a questionnaire. The findings indicated a significant strong positive correlation between pre-service teachers' life skills and their sense of self-efficacy in teaching $(\mathrm{r}=.624)$. Life skills accounted for 38.9 of the variance in teacher sense of self-efficacy. There were not any significant differences in teacher sense of self-efficacy between males and females, graduates and non-graduates, participants and non-participants in life skills training ( $>00.05)$. The sense of self-efficacy of pre-service teachers with teaching experience was found to be higher than that without it $(\mathrm{p}<0.05)$.
\end{abstract}

Keywords: life skills, self-efficacy, pre-service teachers

\section{Introduction}

\subsection{Introduction the Problem}

The sense of self-efficacy among teachers has been a primary research area in educational sciences. It is widely accepted that teachers with high self-efficacy have greater success in their careers (Woolfolk, Rosoff and Hoy, 1990; Bandura, 1997; Tschannen-Moran and Woolfolk Hoy, 2001; Woolfolk, Hoy and Davis, 2006). There have been fewer studies into how self-efficacy is formed as there is a consensus over the general principles outlined by Bandura (Bandura, 1997, 1999). To contribute to self-efficacy literature, the present study looked into whether life skills could be a basis for self-efficacy among teachers. The study centers on the question whether life skills, reportedly necessary for training healthy and productive individuals (WHO, 1997), could also have an impact on the education of teachers with high self-efficacy. The concepts of life skills and teacher self-efficacy are defined below so that the theoretical relationship between the two could be appreciated.

\subsubsection{Life Skills}

Tasks to do, alternatives to choose from, and problems to deal with are part of a person's everyday life. Being a social animal, he or she is also obliged to interact with others and get adapted to the society at large. The adaptation process includes the ability to choose the right thing and cope with arising problems, at which not everyone is equally good. People who use drugs, get involved in crime, resort to violence, or fail in their jobs, i.e. those who cannot adapt, are a fact of life. The World Health Organization took an alternative approach and put forward the idea that individuals could be trained to acquire life skills to become healthy and happy. Development of life skills is based on the premise that individuals should be trained to make correct decisions, set objectives, get along with others etc. For example, if the aim is to protect someone from developing drug addiction, then they should be equipped with the ability to make correct decisions. WHO defines life skills as abilities that enable the individual to cope with everyday challenges (WHO, 1997). Life skills are abilities that empower them to make healthier, better and appropriate decisions, struggle with challenges and replace negative behaviors with positive behaviors. UNICEF (2012) defines life skills as a broad group of psychological and interpersonal skills that may help the individual to make conscious decisions, establish active interaction, and develop self-management skills so that he or she can lead a healthy and productive life. Danish, Forneris, Hodge 
and Heke (2014) define life skills as those that get the individual to be successful in areas of life such as home, school, work and neighborhood.

When WHO first proposed the development of life skills, it defined ten different skills in five categories, which are: problem solving and decision-making skills, critical and creative thinking skills, communication and interpersonal skills, self-awareness and empathy sills, and skills for coping with stress and emotions. WHO also emphasized that these skills were not absolute or universal and new skills could be added depending on the culture and circumstances. Danish, Forneris, Hodge and Heke (2014) put life skills under four categories as behavioral (communicating effectively with peers and adults), cognitive (making effective decisions), interpersonal (being assertive) and intrapersonal (setting goals). Danish and Donohue (1995) and Danish and Nellen (1997) made additions to life skills as physical (e.g. right posture), behavioral (e.g. effective communication) and cognitive (e.g. effective decision-making). Catalano, Berglund, Ryan, Lonczak and Hawkins (1998) expression that educational programs for young people focus on self-efficacy, healthy social and intrapersonal behaviors, interaction with adults and peers as well as social, emotional, cognitive and/or behavioral competences. The SUPER program, in particular, was designed to develop the ability to set goals, cope with problems, and think positively (Danish, Forneris and Wallace, 2005; Brunelle, Danish and Forneris, 2007). UNICEF (2012) listed reasoning, negotiation, coping with stress, critical thinking and decision making among life skills necessary for leading a healthy life. As can be seen, many other skills have been provided in addition to WHO's definition. Although these skills may look different on the surface, they work together in everyday life. The life skills defined above are acquired in the social environment and through schooling. The reason why WHO and UNICEF stress the acquisition of these skills is that they should not be left to chance. There have been a number of practical implementations of life skills training, particularly through a variety of programs offered by educational institutions (Gazioğlu \& Canel, 2015; Ümmet \& Demirci, 2017). The USA leads the field with a vast number projects and research studies that teach life skills through sports activities (Danish, Petitpasn, \& Hale, 1995; Danish, Nellen, \& Owens, 1996; Papacharisis, Goudas, Danish, \& Theodorakis, 2005; Danish, Forneris, \& Wallace, 2005; Martinek, Schilling, \& Hellison, 2006; Holt \& Jones, 2007). The findings of these studies indicate that life skills could be taught using sports training programs. Although these programs aim to equip participants with basic life skills, others strive to keep them away from or wean them off harmful habits. Programs in the latter group effectively target smoking (Botvin \& Kantor, 2000; Sorensen, Gupta, Nagler, \& Viswanath, 2012), prevention of alcohol consumption (Botvin \& Kantor, 2000; Botvin, Griffin, Paul, \& Macaulay, 2003; Spaeth, Weichold, Silbereisen, \& Wiesner, 2010), and drug abuse (Botvin \& Griffin, 2014). The overall result suggests that life skills play a significant role in helping young people become healthy and productive adults.

Turkish Ministry of Education defines the participant in educational programs as an enterprising, determined individual who can produce knowledge, use information operationally in everyday life, solve problems, think critically, communicate and empathize with others, and contribute to the society and culture (MEB, 2018). The skills targeted in this definition are basically made up life skills, overlapping with four-skills (problem solving, critical thinking, communication and empathy) as defined by WHO.

\subsubsection{Sense of Self-Efficacy Among Teachers}

Modern societies, which perceive high-class and multidimensional education of tomorrow's adults to be important, prioritize teaching-learning activities at school. The main indicator of success at school is typically academic achievement, which takes place if all the shareholders in the school community work together. Of all the shareholders, teachers have the most critical role. Teachers' success does not ensure success per se, yet their failure is sure to have a negative impact on student development. Therefore, any factor that might lead to teacher success or failure has been an area of educational research, and sense of self-efficacy is a favorite topic among researchers due to its impact on both the teacher and the student.

Self-efficacy is based on Bandura's social-cognitive learning theory (Bandura, 2006). According to Bandura $(1997,1986)$, sense of self-efficacy are a person's judgments about their abilities in planning and maintaining activities that are necessary for executing a task. A person's belief in their abilities has an effect on their motivation to act, determination and perseverance. Because it is unique to a field and circumstance (Bandura, 1997), sense of self-efficacy is designated and defined accordingly. Sense of self-efficacy among teachers, consequently, comes to mean a distinct construct within sense of self-efficacy, hence a separate definition. Tschannen-Moran and Woolfolk (2001) indicate that teachers' sense of self-efficacy is a teacher judgment about his or her ability to bring about academic output with de-motivated and difficult students. Skaalvik and Skaalvik (2007), Soodak and Podell (1996) and Wheatley (2005) define teachers' sense of self-efficacy as teachers' beliefs in their ability in planning, implementation and maintenance to achieve educational objectives. 
Teachers' sense of self-efficacy is a motivational element that reflects a person's sense rather than their actual performance. A teacher's actual ability can be below or above their sense (Bandura, 1997). In other words, sense of self-efficacy is concerned not with the person's judgment about their own qualifications but with their belief about what they can accomplish (Bong \& Skaalvik, 2003; Zimmerman \& Cleary, 2006). Moreover, teachers' sense of self-efficacy is multidimensional and discipline-specific (Zimmerman \& Cleary, 2006) and varies according to the group of students and the topic of investigation (Ross, Cousins, \& Gadella, 1996). A high degree of sense in an area does not ensure having a high degree in another area (Schunk \& Pajares, 2009).

There are basically four variables that may impact sense of self-efficacy about a teacher's ability of planning, implementation and class management. The first of these variables is the teacher's teaching experience of a particular class and group of students. The second variable is influenced by the experiences of colleagues and particularly individuals set as role models. Thirdly, it is shaped by individuals such as superiors who make comments on their future success or failure. Finally, the teacher's emotions, attitudes etc. feed their sense of self-efficacy (Bandura, 1997, 1999; Schunk \& Pajares, 2009).

Sense of self-efficacy plays a critical role when teachers choose teaching methods, plan lessons, instruct classes, and deal with problems (Bandura, 1997). Their sense of self-efficacy is related to their behavior in class as well as student motivation and academic achievement (Ashton \& Webb, 1986; Anderson, Greene, \& Loewen, 1988; Midgley, Feldlaufer, \& Eccles, 1989; Ross, 1992). High self-efficacy has influenced teachers' performance and motivation (Bandura, 1997; Woolfolk, Hoy, \& Davis, 2006). Teachers with a sense of high self-efficacy are more prospering (Appleton \& Kindt, 2002), more eager to deal with outfaces (Ramey- Gassert, Shroyer, \& Staver, 1996), more dedicated to teaching (Riggs \& Enochs, 1990), and more organized, prepared and sensitive to student needs (Tschannen-Moran \& Woolfolk Hoy, 2001-2002). There is also a relationship between teachers' sense of self-efficacy and the teaching methods that are implemented. Teachers with a sense of low self-efficacy allow more for the subject and teacher-centered activities (Appleton \& Kindt, 2002), while those with sense high self-efficacy have more student-centered classes (Guskey, 1988; Cousins \& Walker, 1995; Watters \& Ginns, 2000).

Teachers' sense of self-efficacy in teaching and classroom management has an impact on classroom atmosphere, which has an impact on students' sense of self-efficacy in that class. If the teacher's sense of self-efficacy is low, the students will likely have a sense of lower self-efficacy in that class. Moreover, a sense of low self-efficacy of the overall school leads to a decrease in students' sense of self-efficacy (Bandura, 1999; Schunk \& Pajares, 2009). In fact, there is a mutual interaction between student achievement and teacher self-efficacy (Raudenbush, Rowan, \& Cheong, 1992; Ross, 1998). High self-efficacy leads to success (Moore \& Esselman, 1992; Ross, 1992). Self-efficacy of teachers is higher in schools where students are high achievers. In contrast, teachers who teach academically low students have a sense of lower self-efficacy (Raudenbush, Rowen, \& Cheong, 1992). Teachers' sense of self-efficacy is influenced positively by the pleasant atmosphere in school (Moore and Esselman, 1992), being compelled by other teachers to succeed (Hoy \& Woolfolk, 1993), and friendly attitudes of school administrators (Hipp \& Bredeson, 1995), and negatively influenced by discipline problems in school (Skaalvik \& Skaalvik, 2010; Collie, Shapka, \& Perry, 2012; Fernet, Guay, Senécal, \& Austin, 2012) and low student motivation (Skaalvik \& Skaalvik, 2016). Teachers' sense of self-efficacy is also relevent to job satisfaction (Caprara, Barbaranelli, Borgogni, \& Steca, 2003; Türkoğlu, Cansoy, \& Parlar, 2017), burnout (Savaş, Bozgeyik, \& Eser, 2014), attitudes toward the profession (Ekici, Çıbık, \& Fettahlıoğlu, 2014; Dadandı, Kalyon, \& Yazıc1, 2016; Nakip \& Özcan, 2016), and attitudes toward teaching (Emre \& Ünsal, 2017).

Teachers' sense of self-efficacy start to form during teacher education period and tend to increase across school years (Hoy ve Woolfolk, 1990; Wenner, 2001), but it starts to fall at the end of the first teaching year (Woolfolk Hoy, 2000; Moseley, Reinke \& Bookour, 2003).

A survey of the literature did not reveal any studies into the relationship between life skills in general and teachers' sense of self-efficacy. Available studies have found a high correlation between distinct life skills and teachers' sense of self-efficacy as well as distinct life skills and various fields. Studies conducted by Altunçekiç, Yaman and Koray (2005) and Aylar and Aksin (2011) have identified a moderate correlation between teachers' sense of self-efficacy and problem solving ability. In addition, sense of self-efficacy was found to correlate with critical thinking (Mahmoudi \& Asadi, 2016; Dehghani, Pakmehr, \& Malekzadeh, 2011), creative thinking (Shaabani, Maktabi, Yeylagh, \& Morovati, 2011), and self-awareness (Bong \& Skaalvik, 2003; Pajares \& Schunk, 2001). 


\subsection{Problem Statement}

This study was designed to make a contribution to research literature by investigating whether life skills in general predict teachers' sense of self-efficacy, i.e. whether life skills are one of the sources of sense of self-efficacy. Answers were thus sought for the following research questions:

1) Is there a relationship between pre-service teachers' life skills and sense of self-efficacy?

2) Do pre-service teachers' life skills predict their sense of self-efficacy?

3) Is there a differentiation between pre-service teachers' life skills and sense of self-efficacy with respect to their gender, status of graduation, prior attendance to life skills training and teaching experience on life skills?

\section{Method}

\subsection{Research Model}

This study aimed to find out the extent to which pre-service teachers' life skills predict their sense of self-efficacy. A relational screening model within the quantitative research paradigm was used for the research. A relational screening model is developed to find the relationship and causality relationship between two or more variables (Büyüköztürk, Kılıç, Çakmak, Erkan, Akgün, Karadeniz and Demirel, 2017). This study investigated pre-service teachers' life skills, their sense of self-efficacy and various variables that defined pre-service teachers.

\subsection{Study Group}

It was collected data by purposive sampling technique. The results of the research were collected on the pre-service teacher participating in the Pedagogical Formation Program of Mimar Sinan Fine Arts University. There are three reasons why this study group is preferred. First the Primary Pedagogical Formation Program consists of students with a 4-year undergraduate program who have graduated or are still pursuing a program of different universities that can be assigned to teaching. In this sense, the group is a homogenous structure. This differentiates the study group in terms of life skills, whether they must graduate from different undergraduate programs, are working or are still in student life. Second, the graduates differed in their attitudes towards teaching as regards the fact that they worked for a certain period of time as a contracted candidate trainer in private institutions or were still working and the students still studying at undergraduate level. The third, the research group, was preferred because of the researcher's ability to serve at the same university and ease of application. 195 of the students in the program participated in the study. 154 participants were female (79 \%), and 41 were male $(21 \%)$. A great majority of them were over 23 year of age $(87.7 \%)$, and most were recent graduates $(67.8 \%)$. The research data are given in Table 1.

Table 1. Descriptive information about the participants

\begin{tabular}{llll}
\hline Variables & & Frequency & Percentage \\
\hline \multirow{2}{*}{ Gender } & Female & 154 & 79.0 \\
& Male & 41 & 21.0 \\
\hline \multirow{3}{*}{ Age } & 21 years old & 7 & 3.6 \\
& 22 years old & 17 & 8.7 \\
\hline \multirow{2}{*}{ Graduate or student } & 23 years old & 171 & 87.7 \\
\hline \multirow{2}{*}{ Participation in life skills training } & Graduate & 134 & 68.7 \\
& Student & 61 & 31.3 \\
\hline \multirow{2}{*}{ Experience of teaching } & No & 22 & 11.3 \\
& Yes & 173 & 88.7 \\
\hline
\end{tabular}

\subsection{Assessment Tools}

The data for the study was collected using a life skills scale, a teacher self-efficacy scale and a questionnaire.

Life Skills Scale: A scale developed by Bolat and Balaban (2017) was used to measure the participants' levels of life skills. The scale was developed to measure 10 life skills defined by WHO in five categories The validity and reliability studies of your scale were conducted on 493 pre-service teachers. The exploratory factor analysis on the scale revealed that the scale had five factors and explained $47.70 \%$ of the total variance. The Cronbach alpha 
value of the whole scale was .90 ; and for sub-dimensions between .82 and .66 . The validity and reliability studies of your scale were conducted on 493 pre-service teachers. The exploratory factor analysis on the scale revealed that the scale had five factors and explained $47.70 \%$ of the total variance. The Cronbach alpha value for the whole scale is .90 , ranging from .82 to .66 for subscales.

The five sub-dimensions of the scale are skills in dealing with emotions and stress, decision-making and problem-solving skills, skills in establishing empathy and self-efficacy, skills in creative thinking and critical reasoning.The life skills scale is composed of 30 Likert-type items. A higher score on the scale indicates a higher skill level.

Teachers' Sense of Self-Efficacy Scale: Developed by Tschannen-Moran and Woolfolk-Hoy and translated into Turkish by Çapa, Çakıroğlu and Sarıkaya (2005), teachers' sense of self-efficacy scale was used to measure the participants' sense of self-efficacy. Confirmatory Factor Analysis was used for validity analysis in the process of adapting the scale to Turkish. In the study conducted on 628 pre-service teachers, the structure of the adapted scale was similar to the original scale (RMSA $=.07$, TLI and CFI $>.95$ ). As a result of the reliability analysis tested with Cronbach alpha, the overall score of the scale was .93, for the self-efficacy perception subscale for instructional strategy .82 , for self-efficacy perception subscale for classroom management .86 , and for self-efficacy perception sub-dimension for student participation .84 Confirmatory Factor Analysis was used for validity analysis in the process of adapting the scale to Turkish. In a study of 628 pre-service teachers, the structure of the adapted scale was similar to the original scale (RMSA $=.07$, TLI and CFI $>.95$ ). As a result of the reliability analysis tested with Cronbach alpha, the overall score of the scale was $.93, .82$ for the self-efficacy perception subscale for instructional strategy, .86 for self-efficacy perception subscale for classroom management, and .84. The assessment tool includes three dimensions: sense of self-efficacy toward teaching strategy, sense of self-efficacy toward class management, and sense of self-efficacy toward student participation. There are 24 Likert-type items on the scale, and A higher score on the scale indicates a higher skill level.

Questionnaire: The questionnaire was developed by the researcher. The six questions on the questionnaire were about gender, age, department, university, whether the participant had any life skills training, and whether the participant had teaching experience.

\subsection{Data Collection}

The data were collected in April 2017. Permissions were granted by the university administration before the study. The participants were told about the aim of the study and the tests to be administered, and the volunteers were given all the three surveys at the same time.

\subsection{Data Analysis}

The data collected for the study were first entered into the computer and then analyzed using IBM SPSS 21.0. To decide on the data analysis type, the scores on the Life Skills Scale and Teachers' Self-Efficacy Scale were checked for normality. The Shapiro-Wilk test showed that the scores had a normal distribution ( $>00.05)$. (Table 2). Independent group $t$ tests were used to compare the scores from the two scales and the participants' characteristics, i.e. their gender, their age, their department, their university, whether the participant had any like skills training, and whether the participant had teaching experience. The Pearson correlation test was used to analyze whether there was any relationship between the scores obtained from the Life Skills Scale and Teachers' Self-Efficacy Scale. Whether the participants' life skills predicted their sense of self-efficacy was tested using simple linear regression analysis. A significance level of .05 was accepted for all the tests.

Table 2 . The normality values observed by the Shapiro-Wilk test of the variables

\begin{tabular}{lccc}
\hline & & Shapiro-Wilk & p \\
\cline { 2 - 4 } & Statistic & df &, 120 \\
\hline Teacher Sense of Self-Efficacy-Total &, 988 & 189 &, 126 \\
S.S.E. Toward Student Participation. &, 988 & 189 &, 143 \\
S.S.E. Toward Teaching Strategy. &, 989 & 189 &, 100 \\
S.S.E. Toward Classroom Management. &, 988 & 189 &, 311 \\
Life Skills-Total &, 991 & 189 &, 278 \\
Skills in dealing with emotions and stress &, 991 & 189 &, 085 \\
Skills in establishing empathy and self-awareness &, 986 & 189 &, 225 \\
Skills in decision-making and problem-solving &, 990 & 189 &, 120 \\
Skills in creative thinking and critical reasoning &, 988 & 189 &, 110 \\
Skills in communication/interpersonal relations &, 987 & 189 & \\
\hline
\end{tabular}




\section{Results}

This section includes findings about the statistical analyses conducted to find answers to the research questions. The first findings are about the correlation analysis of whether there is any relationship between the Life Skills Scale and Teachers' Self-Efficacy Scale as well as between the scores obtained from the sub-dimensions of the scales. The findings from this analysis are presented in Table 3.

Table 3. The relationship between the life skills scale and teachers' self-efficacy scale as well as between the scores obtained from the sub-dimensions of the scales

\begin{tabular}{|c|c|c|c|c|c|c|c|c|c|c|}
\hline & & 1 & 2 & 3 & 4 & 5 & 6 & 7 & 8 & 9 \\
\hline \multirow[t]{2}{*}{ Teacher Sense of Self-Efficacy-1 } & $\mathbf{r}$ & & & & & & & & & \\
\hline & $\mathbf{p}$ & & & & & & & & & \\
\hline S.S.E. Toward Student & $\mathbf{r}$ & .915 & & & & & & & & \\
\hline Participation-2 & $\mathbf{p}$ & .000 & & & & & & & & \\
\hline S.S.E. Toward Teaching & $\mathbf{r}$ & .916 & .808 & & & & & & & \\
\hline Strategy-3 & $\mathbf{p}$ & .000 & .000 & & & & & & & \\
\hline S.S.E. Toward Classroom & $\mathbf{r}$ & .884 & .692 & .689 & & & & & & \\
\hline Management-4 & $\mathbf{p}$ & .000 & .000 & .000 & & & & & & \\
\hline \multirow{2}{*}{ Life Skills-Total-5 } & $\mathbf{r}$ & .624 & .597 & .576 & .525 & & & & & \\
\hline & $\mathbf{p}$ & .000 & .000 & .000 & .000 & & & & & \\
\hline \multirow{2}{*}{$\begin{array}{l}\text { Skills in dealing with emotions } \\
\text { and stress- } 6\end{array}$} & $\mathbf{r}$ & .428 & .398 & .369 & .372 & .798 & & & & \\
\hline & $\mathbf{p}$ & .000 & .000 & .000 & .000 & .000 & & & & \\
\hline \multirow{2}{*}{$\begin{array}{l}\text { Skills in establishing empathy } \\
\text { and self-awareness- } 7\end{array}$} & $\mathbf{r}$ & .551 & .529 & .541 & .428 & .832 & .530 & & & \\
\hline & $\mathbf{p}$ & .000 & .000 & .000 & .000 & .000 & .000 & & & \\
\hline \multirow{2}{*}{$\begin{array}{l}\text { Skills in decision-making and } \\
\text { problem-solving- } 8\end{array}$} & $\mathbf{r}$ & .621 & .609 & .555 & .535 & .819 & .449 & .637 & & \\
\hline & $\mathbf{p}$ & .000 & .000 & .000 & .000 & .000 & .000 & .000 & & \\
\hline \multirow{2}{*}{$\begin{array}{l}\text { Skills in creative thinking and } \\
\text { critical reasoning-9 }\end{array}$} & $\mathbf{r}$ & .498 & .490 & .497 & .403 & .770 & .432 & .600 & .704 & \\
\hline & $\mathbf{p}$ & .000 & .000 & .000 & .000 & .000 & .000 & .000 & .000 & \\
\hline \multirow{2}{*}{$\begin{array}{l}\text { Skills in communication/ } \\
\text { interpersonal relations }-10\end{array}$} & $\mathbf{r}$ & .446 & .419 & .415 & .394 & .716 & .530 & .513 & .495 & .449 \\
\hline & $\mathbf{p}$ & .000 & .000 & .000 & .000 & .000 & .000 & .000 & .000 & .000 \\
\hline
\end{tabular}

The results of the correlation analysis given in Table show that there is a significant, positive strong relationship between the participants' sense of self-efficacy and their life skills $(r=.624, p<0.001)$. Teachers' sense of self-efficacy is strongly correlated with the sub-dimensions of the life skills sale. Teachers' sense of self-efficacy is also positively and significantly correlated with the following sub-dimensions of the life skills scale: skills in dealing with emotions and stress, skills in establishing empathy and self-awareness, skills in decision-making and problem-solving, skills in creative thinking and critical reasoning, and skills in communication/interpersonal relations at levels of $.428, .551, .621, .498$ and .446 , respectively $(\mathrm{p}<0.001)$. Furthermore, the life skills scale is positively and significantly correlated with the following sub-dimensions of the sense of self-efficacy scale: sense of self-efficacy toward student participation, sense of self-efficacy toward teaching strategy, and sense of self-efficacy toward classroom management at levels of $.597, .576$ and $.525(\mathrm{p}<0.001)$. All these results indicate that teachers' sense of self-efficacy is highly correlated with life skills.

The correlation analyses show that a regression analysis can be conducted between the two variables. Table 4 present the results of the simple linear regression analysis about the extent to which the participants' life skills predict the level of teachers' sense of self-efficacy.

Table 4. Results of regression analysis about the extent to which the participants' life skills predict the level of teachers' sense of self-efficacy

\begin{tabular}{lcccccccccc}
\hline & Av. & Sd. & $\mathbf{R}$ & $\mathbf{R}^{2}$ & $\mathbf{F}$ & $\mathbf{p}$ & $\mathbf{B}$ & Std. Err & $\mathbf{t}$ & $\mathbf{p}$ \\
\hline $\begin{array}{l}\text { Teacher Sense } \\
\text { of Self-Efficacy }\end{array}$ & 6.97 & .81 & .624 & .389 & 122.87 & .000 & 2.559 & .401 & 6.388 & .000 \\
Life Skills & 3.97 & .45 & & & & & & & & \\
\hline
\end{tabular}


According to the results of the regression analysis, the participants' life skills predict their teacher self-efficacy at a significant level $(\mathrm{F}=122.87, \mathrm{p}<0.001)$. The findings indicate that life skills account for 38.9 percent of the variance in the participants' teacher self-efficacy.

The final findings are about a comparison of the participants' scores from teachers' sense of self-efficacy scale and life skills scale with respect to their being male or female, graduate or non-graduate, former participant or non-participant in life skills training, and experienced or inexperienced in teaching. These analyses were conducted using $t$ tests. The results of the analyses did not reveal any significant differences, thus they are presented without a table.

According to the independent groups $t$ tests conducted on the data, there is a similarity between the overall scores of the participants' sense of self-efficacy obtained from teachers' sense of self-efficacy scale (with respect to their being male or female, graduate or non-graduate, former participant or non-participant in life skills training, and experienced or inexperienced in teaching) and the scores from the sub-dimensions of 'the sense of self-efficacy toward student participation,' 'the sense of self-efficacy toward teaching strategy,' "'the sense of self-efficacy toward classroom management $(\mathrm{p}>0.05)$.' These results show that the participants' sense of self-efficacy is not influenced by the variables of gender, having graduated and having participated in a course about life skills.

In the same vein, there is a similarity between the overall scores of the participants from the life skills scale (with respect to their being male or female, graduate or non-graduate, and former participant or non-participant in life skills training) and the scores from the sub-dimensions of 'skills in dealing with emotions and stress,' 'skills in establishing empathy and self-awareness,' 'skills in decision-making and problem-solving,' skills in creative thinking and critical reasoning,' and 'skills in communication/interpersonal relations ( $p>0.05)$.' These results show that the participants' life skills are not influenced by the variables of gender, having graduated and having participated in a course in life skills.

Table 5. T-test results about the comparison of scores the participants with and without prior teaching experience

\begin{tabular}{|c|c|c|c|c|c|c|}
\hline Scales & $\begin{array}{l}\text { Prior teaching } \\
\text { experience }\end{array}$ & $\mathbf{N}$ & Av. & Std. Dev. & $\mathbf{t}$ & $\mathbf{p}$ \\
\hline \multirow{2}{*}{ Teacher Sense of Self-Efficacy } & Yes & 73 & 7.12 & .76 & \multirow{2}{*}{2.033} & \multirow{2}{*}{.043} \\
\hline & No & 122 & 6.88 & .82 & & \\
\hline \multirow{2}{*}{ S.S.E. Toward Student Participation } & Yes & 73 & 7.16 & .83 & \multirow{2}{*}{1.712} & \multirow{2}{*}{.088} \\
\hline & No & 122 & 6.96 & .82 & & \\
\hline \multirow{2}{*}{ S.S.E. Toward Teaching Strategy } & Yes & 73 & 7.29 & .82 & \multirow{2}{*}{2.258} & \multirow{2}{*}{.025} \\
\hline & No & 122 & 7.00 & .91 & & \\
\hline \multirow{2}{*}{$\begin{array}{l}\text { S.S.E. Toward Classroom } \\
\text { Management }\end{array}$} & Yes & 73 & 6.90 & .89 & \multirow{2}{*}{1.406} & \multirow{2}{*}{.161} \\
\hline & No & 122 & 6.71 & .94 & & \\
\hline \multirow{2}{*}{ Life Skills } & Yes & 73 & 4.04 & .44 & \multirow{2}{*}{1.708} & \multirow{2}{*}{.089} \\
\hline & No & 122 & 3.93 & .45 & & \\
\hline \multirow{2}{*}{$\begin{array}{l}\text { Skills in dealing with emotions and } \\
\text { stress }\end{array}$} & Yes & 73 & 3.67 & .65 & \multirow{2}{*}{2.309} & \multirow{2}{*}{.022} \\
\hline & No & 122 & 3.45 & .66 & & \\
\hline \multirow{2}{*}{$\begin{array}{l}\text { Skills in establishing empathy and } \\
\text { self-awareness }\end{array}$} & Yes & 73 & 4.17 & .44 & \multirow{2}{*}{1.413} & \multirow{2}{*}{.159} \\
\hline & No & 122 & 4.07 & .49 & & \\
\hline \multirow{2}{*}{$\begin{array}{l}\text { Skills in decision-making and } \\
\text { problem-solving }\end{array}$} & Yes & 73 & 4.11 & .52 & \multirow{2}{*}{.392} & \multirow{2}{*}{.695} \\
\hline & No & 122 & 4.07 & .51 & & \\
\hline \multirow{2}{*}{$\begin{array}{l}\text { Skills in creative thinking and } \\
\text { critical reasoning }\end{array}$} & Yes & 73 & 4.19 & .50 & \multirow{2}{*}{.894} & \multirow{2}{*}{.373} \\
\hline & No & 122 & 4.12 & .56 & & \\
\hline Skills in communication & Yes & 73 & 4.18 & .58 & \multirow{2}{*}{1.115} & \multirow{2}{*}{.266} \\
\hline /interpersonal relations & No & 122 & 4.08 & .63 & & \\
\hline
\end{tabular}

There is a significant difference between the overall scores of the participants with and without teaching experience in teacher self-efficacy scale and the scores obtained from the sub-dimension of "sense of self-efficacy toward teaching strategy" $(p<0.05)$. Those with teaching experience have a higher sense of teacher self-efficacy. Although those with experience also have higher averages in the other sub-dimensions, the difference is not statistically significant $(\mathrm{p}>0.05)$. This result shows that having teaching experience, that is having met the class and students, has a positive impact on teacher self-efficacy. 
There is a significant difference between the score averages of the participants with and without teaching experience in life skills scale and its sub-dimensions. The participants with prior teaching experience have higher average scores in all the dimensions, yet the difference is significant in the sub-dimension of "skills in dealing with emotions and stress $(\mathrm{p}>0.05)$. There is no significant difference between the overall scale and other sub-dimensions. This result shows that having teaching experience, that is having met the class and students, has a positive impact on life skills.

\section{Discussion}

This study aimed at revealing the effects of demographic factors such as gender, status of graduation, prior attendance to life skills training and teaching experience on life skills and sense of teacher self-efficacy as well as at identifying the relationship between life skills and sense of teacher self-efficacy.

The main finding of the study is that there is a moderate correlation between pre-service teachers' life skills and sense of self-efficacy and that life skills are a significant predictor of sense of self-efficacy (39\%). Sense of teacher self-efficacy is a teacher's judgment about his or her ability to bring about academic output with de-motivated and difficult students (Tschannen-Moran \& Woolfolk Hoy, 2001). Sense of self-efficacy is a person's faith in oneself and is a motivational element (Bandura, 1997). Teachers who have a high sense of self-efficacy are not deterred by challenges (Ramey-Gassert, Shroyer, \& Staver, 1996), insistent on what they want to do (Riggs \& Enochs, 1990), and organized (Tschannen-Moran \& Woolfolk Hoy, 2001, 2002). The abovementioned characteristics are, in a way, a reflection of the characteristics of an individual who is successful at what they do, and life skills are defined as abilities that enable an individual to succeed in areas where they live such as home, school, work and neighborhood (Danish \& Donahue, 1995; Danish, Forneris, Hodge, \& Heke, 2004). The most fundamental of these skills are problem solving and decision-making skills, critical and creative thinking skills, communication and interpersonal skills, self-awareness and empathy sills, and skills in coping with stress and emotions (WHO, 1997). Although there is not any previous research that addresses the relationship between the two skills as a whole, it can be inferred that individuals with high life skills have the ability and self-confidence to do any job. It has been found that the sub-dimensions of life skills correlate with sense of self-efficacy, which supports the theory. Studies by Altunçekiç, Yaman and Koray (2005) and Aylar and Aksin (2011) have found a moderate correlation between teachers' senses of self-efficacy and problem solving ability. Studies by Mahmoudi and Asadi (2016) and Dehghani, Pakmehr and Malekzadeh (2011) on language students found that sense of self-efficacy correlates with critical thinking. Shaabani, Maktabi, Yeylagh and Morovati' (2011) study with language students identified a correlation between sense of self-efficacy and creative thinking. Bong and Skaalvik found that sense of self-efficacy and self-awareness were related. Pajares and Schunk (2001) stressed that self-awareness was related with self-efficacy. In conclusion, it seems safe to say that life skills are related to self-efficacy.

According to the second finding in the study, the life skills and senses of teacher self-efficacy among male and female pre-service teachers are similar, which shows that gender is not a determinant variable in life skills or sense of teacher self-efficacy. Previous research offers contradictory results about the gender difference in sense of self-efficacy among pre-service teachers. Tschannen-Moran and Hoy (2007), Britner and Pajares (2006) and Çakiroglu, Çakiroglu and Boone (2005) identified that sense of teacher self-efficacy did not vary according to gender, a result confirmed by this study. On the other hand, Bursal (2010) found that female pre-service teachers had a higher sense of self-efficacy, while Klassen and Chiu (2010) and Çakıroğlu and Işıksal (2009) found that male pre-service teachers had a higher sense of self-efficacy. There is no previous study that researched into the case of life skills as a whole for different genders, but there seems to be differences in the sub-dimensions of life skills between males and females. Some studies confirm the findings of this study, while others do not. Can and Kaymakçı (2015) found that female pre-service teachers were slightly higher in critical thinking, whereas Sakar and Aybek (2016) identified no difference. There are also studies that identified no difference between the creative thinking skills of male and female pre-service teachers (Yıldız, Zırhlıŏlu, Yalçınkaya, \& Güven, 2011; Aydoğdu \& Yüksel, 2013) as well as those that identified a difference for females (Gök \& Erdoğan, 2011; Erdoğan, Ercoşkun, and Balc1, 2016). As can be seen, there is no consensus over the effects of gender on life skills.

The last finding obtained in the study is that having met students and having teaching experience increase pre-service teachers' sense of self-efficacy. Pre-service teachers' sense of teacher self-efficacy tends to increase during teacher education period (Hoy ve Woolfolk, 1990; Wenner, 2001). Sense of self-efficacy starts to fall once teachers start working (Woolfolk Hoy, 2000; Moseley, Reinke, \& Bookour, 2003). It can be said that the findings in the study do not support literature completely, which could result from the fact that the pre-service teachers participating in the study were from among those who participated in a pedagogical formation course. 
The group that participated in the study was only two months into the course. An early date in the course may indicate that the participants were not accustomed to the idea of being a teacher, which might explain why pre-service teachers with teaching experience had a higher sense of self-efficacy.

To sum up, it can be said that there is a moderate correlation between pre-service teachers' life skills and sense of self-efficacy and that life skills are a significant predictor of sense of self-efficacy. This result suggests that individuals should be trained in life skills so that they can become more effective and productive teachers. To do this, activities can be held during teaching education process that aim to equip students with life skills such as problem solving and critical thinking.

\section{References}

Altunçekiç, A., Yaman, S., \& Koray, Ö. (2005). An investigation into pre-service teachers' level of self-efficacy beliefs and their problem-solving skills (The case of Kastamonu province). Kastamonu Educational Journal, 93.

Anderson, R. N., Greene, M. L., \& Loewen, P. S. (1988). Relationships among teachers' and students' thinking skills, sense of efficacy, and student achievement. Alberta Journal of Educational Research, 34(2),

Appletton,165.; \& Kindt, I. (2002). Beginning elementary teachers' development as teachers of science. Journal of Science Teacher Education, 13(1), 43-61. https://doi.org/10.1023/A:1020809916037

Ashton, P. T., \& Webb, R. B. (1986). Teachers' sense of efficacy, classroom behavior, and student achievement. Teachers' sense of efficacy and student achievement, 125-144.

Aydoğdu, N., \& Yüksel, İ. (2013). An investigation of the relationship between pre-service primary school math teachers' level of creativity and their beliefs about and attitudes toward math history. Journal of Education and Teaching Research, 2(4), 186-194.

Aylar, F., \& Aksin, A. (2011). An investigation into the level of self-efficacy beliefs and problem-solving skills among pre-service teachers of social sciences (The case of Amasya). Ahi Evran University Journal of Kirşehir Faculty of Education, 12(3).

Bandura, A. (1986). Social foundations of thought and action. A social cognitive theory. Englewood Cliffs, NJ: Prentice-Hall.

Bandura, A. (1988). Organizational Application of Social Cognitive Theory. Australian Journal of Management, 13(2), 275-302. https://doi.org/10.1177/031289628801300210

Bandura, A. (1994). Self-efficacy. In V. S. Ramachaudran (Ed.), Encyclopedia of human behavior (Vol. 4, pp. 71-81). New York: Academic Press. (Reprinted in H. Friedman [Ed.], Encyclopedia of mental health. San Diego: Academic Press, 1998).

Bandura, A. (1997). Self-efficacy: The exercise of control. New York, NY: Freeman.

Bandura, A. (1999). Social cognitive theory of personality. Handbook of personality: Theory and research, 154-196.

Bandura, A. (2006). Adolescent development from an agentic perspective. In F. Pajares \& T. Urdan (Eds.), Self-efficacy beliefs of adolescents (pp. 1-43). Greenwich, CT: Information Age.

Bong, M., \& Skaalvik, E. M. (2003). Academic self-concept and self-efficacy: How different are they really?. Educational Psychology Review, 15(1), 1-40. https://doi.org/10.1023/A:1021302408382

Botvin, G. J., \& Griffin, K. W. (2014). Life skills training: preventing substance misuse by enhancing individual and social competence. New Directions for Student Leadership, 2014(141), 57-65. https://doi.org/10.1002/yd.20086

Botvin, G. J., \& Kantor, L. W. (2000). Preventing alcohol and tobacco use through life skills training. Alcohol Research and Health, 24(4), 250-257.

Botvin, G. J., Griffin, K. W., Paul, E., \& Macaulay, A. P. (2003). Preventing tobacco and alcohol use among elementary school students through life skills training. Journal of Child \& Adolescent Substance Abuse, 12(4), 1-17. https://doi.org/10.1300/J029v12n04_01

Britner, S. L., \& Pajares, F. (2006). Sources of science self-efficacy beliefs of middle school students. Journal of Research in Science Teaching, 43(5), 485-499. https://doi.org/10.1002/tea.20131

Brunelle, J., Danish, S. J., \& Forneris, T. (2007). The impact of a sport-based life skill program on adolescent prosocial values. Applied Developmental Science, 11(1), 43-55. https://doi.org/10.1080/10888690709336722 
Bursal, M. (2010). Turkish preservice elementary teachers' self-efficacy beliefs regarding mathematics and science teaching. International Journal of Science and Mathematics Education, 8(4), 649-666. https://doi.org/10.1007/s10763-009-9179-6

Büyüköztürk, Ş., Çakmak, E. K., Akgün, Ö. E., Karadeniz, Ş., \& Demirel, F. (2017). Scientific Research Methods. Pegem Akademi Publishing.

Çakiroglu, E., \& Isiksal, M. (2009). Preservice elementary teachers' attitudes and self-efficacy beliefs toward mathematics. Egitim ve Bilim, 34(151), 132.

Çakiroglu, J., Çakiroglu, E., \& Boone, W. J. (2005). Pre-service teacher self-efficacy beliefs regarding science teaching: A comparison of pre-service teachers in Turkey and the USA. Science Educator, 14(1), 31.

Can, Ş., \& Kaymakçı, G. (2015). Tendency of pre-service teachers to think critically. Education Sciences, 9(6), 66-83.

Caprara, G. V., Barbaranelli, C., Borgogni, L., \& Steca, P. (2003). Efficacy beliefs as determinants of teachers' job satisfaction. Journal of Educational Psychology, 95(4), 821. https://doi.org/10.1037/0022-0663.95.4.821

Catalano, R. F., Berglund, M. L., Ryan, J. A. M., Lonczak, H. S., \& Hawkins, J. D. (1998). Defining and evaluating positive youth development. Positive youth development in the United States: Research findings on evaluations of positive youth development programs.

Collie, R. J., Shapka, J. D., \& Perry, N. E. (2012). School climate and social-emotional learning: Predicting teacher stress, job satisfaction, and teaching efficacy. Journal of Educational Psychology, 104(4), 1189. https://doi.org/10.1037/a0029356

Cousins, J., \& Walker, C. (1995, June). Personal teacher efficacy as a predictor of teachers' attitudes toward applied educational research. In annual meeting of the Canadian Association for the Study of Educational Administration, Montreal.

Dadandı, İ., Kalyon, A., Yazıcı, H. (2016). The self-efficacy beliefs, anxiety levels and teaching attitudes of pre-service teachers and teacher candidates receiving education in pedagogical formation. Journal of Bayburt Faculty of Education, 11(1).

Danish, S. J., \& Donohue, T. (1995). Understanding media's influence on the development of antisocial and prosocial behavior. Preventing violence in America, 4, 133-155.

Danish, S. J., \& Nellen, V. C. (1997). New roles for sport psychologists: Teaching life skills through sport to at risk youth. Quest, 49, 100-113. https://doi.org/10.1080/00336297.1997.10484226

Danish, S. J., Forneris, T., \& Wallace, I. (2005). Sport-based life skills programming in the schools. Journal of Applied School Psychology, 21(2), 41-62. https://doi.org/10.1300/J370v21n02_04

Danish, S. J., Nellen, V., \& Owens, S. (1996). Community-based life skills programs: Using sports to teach life skills to adolescents. In J. L. Van Raalte \& B. W. Brewer (Eds.), Exploring sport and exercise psychology (pp. 205-225). Washington, DC: American Psychological Association. https://doi.org/10.1037/10186-009

Danish, S. J., Petitpas, A., \& Hale, B. (1995). Psychological interventions: A life development model. In S. M. Murphy (Ed.), Sport psychology interventions (pp. 19-28). Champaign, IL; Human Kinetics Publishers.

Danish, S., Forneris, T., Hodge, K., \& Heke, I. (2004). Enhancing youth development through sport. World Leisure Journal, 46(3), 38-49. https://doi.org/10.1080/04419057.2004.9674365

Dehghani, M., Pakmehr, H., \& Malekzadeh, A. (2011). Relationship between students' critical thinking and self-efficacy beliefs in Ferdowsi University of Mashhad, Iran. Procedia-Social and Behavioral Sciences, 15, 2952-2955. https://doi.org/10.1016/j.sbspro.2011.04.221

Ekici, G., Çıbık, A. S., \& Fettahlıŏlu, P. (2014). The power of biology self-efficacy and self-efficacy toward teaching profession in predicting attitudes toward teaching profession. Gazi University Journal of Gazi Faculty of Education, 34(1).

Emre, Ş. C., \& Ünsal, S. (2017). The investigation of the relationship between secondary school teachers' self-efficacy beliefs and attitude towards teaching. European Journal of Education Studies, 3(6).

Erdoğan, K. Ö. S. E., Ercoşkun, N. Ç., \& Balcı, A. (2016). An investigation of creative thinking and problem solving skills of pre-service teachers in preschool and class teacher departments. Mehmet Akif Ersoy University Journal of Faculty of Education, 1(40). 
Fernet, C., Guay, F., Senécal, C., \& Austin, S. (2012). Predicting intraindividual changes in teacher burnout: The role of perceived school environment and motivational factors. Teaching and teacher education, 28(4), 514-525. https://doi.org/10.1016/j.tate.2011.11.013

Gazioğlu, A. E. İ., \& Canel, A. N. (2015). A school-based prevention model in the fight against addiction: Life skills training. Addicta: The Turkish Journal on Addictions, 2(2), 5-44.

Gök, B., \& Erdoğan, T. (2011). An investigation of class teacher candidates' levels of creative thinking and tendency to think critically. Ankara University Journal of Educational Sciences, 44(2), 29-51.

Guskey, T. R. (1988). Teacher efficacy, self-concept, and attitudes toward the implementation of instructional innovation. Teaching and Teacher Education, 4(1), 63-69. https://doi.org/10.1016/0742-051X(88)90025-X

Hipp, K. A., \& Bredeson, P. V. (1995). Exploring connections between teacher efficacy and principals' leadership behaviors. Journal of School Leadership, 5(2), 136-150.

Hoy, W. K., \& Woolfolk, A. E. (1993). Teachers' sense of efficacy and the organizational health of schools. The Elementary School Journal, 93(4), 355-372. https://doi.org/10.1086/461729

Klassen, R. M., \& Chiu, M. M. (2010). Effects on teachers' self-efficacy and job satisfaction: Teacher gender, years of experience, and job stress. Journal of Educational Psychology, 102(3), 741. https://doi.org/10.1037/a0019237

Mahmoudi, H., \& Asadi, M. (2016). The relationship among autonomy, self-efficacy, and critical thinking of Iranian upper-intermediate EFL learners. Language Education Studies, 2(2), 16-25.

Martinek, T., Schilling, T., \& Hellison, D. R. (2006). The development of compassionate and caring leadership among adolescents. Physical Education \& Sport Pedagogy, 11(2), 141-157. https://doi.org/10.1080/17408980600708346

MEB (2018). Secondary school class curriculum. Retrieved from http://mufredat.meb.gov.tr/ProgramDetay.aspx?PID=343

Midgley, C., Feldlaufer, H., \& Eccles, J. S. (1989). Change in teacher efficacy and student self-and task-related beliefs in mathematics during the transition to junior high school. Journal of educational Psychology, 81(2), 247. https://doi.org/10.1037/0022-0663.81.2.247

Moore, W., \& Esselman, M. (1992, April). Teacher efficacy, power, school climate and achievement: A desegregating district's experience. In annual meeting of the American Educational Research Association, San Francisco.

Moseley, C., Reinke, K., \& Bookout, V. (2003). The effect of teaching outdoor environmental education on elementary preservice teachers' self-efficacy. Journal of Elementary Science Education, 1-14. https://doi.org/10.1007/BF03174740

Nakip, C., \& Özcan, G. (2016). The relationship between preservice teachers' self-efficacy beliefs toward teaching profession and their attitudes toward teaching profession. Mersin University Journal of Faculty of Education, 12(3).

Pajares, F., \& Schunk, D. H. (2001). Self-beliefs and school success: Self-efficacy, self-concept, and school achievement. Perception, 11, 239-266.

Papacharisis, V., Goudas, M., Danish, S. J., \& Theodorakis, Y. (2005). The effectiveness of teaching a life skills program in a sport context. Journal of Applied Sport Psychology, 17(3), 247-254. https://doi.org/10.1080/10413200591010139

Ramey-Gassert, L., Shroyer, M. G., \& Staver, J. R. (1996). A qualitative study of factors influencing science teaching self-efficacy of elementary level teachers. Science Education, 80(3), 283-315. https://doi.org/10.1002/(SICI)1098-237X(199606)80:3<283::AID-SCE2>3.0.CO;2-A

Raudenbush, S. W., Rowan, B., \& Cheong, Y. F. (1992). Contextual effects on the self-perceived efficacy of high school teachers. Sociology of Education, 150-167. https://doi.org/10.2307/2112680

Riggs, I. M., \& Enochs, L. G. (1990). Toward the development of an elementary teacher's science teaching efficacy belief instrument. Science Education, 74(6), 625-637. https://doi.org/10.1002/sce.3730740605

Ross, J. A. (1992). Teacher efficacy and the effects of coaching on student achievement. Canadian Journal of Education/Revue canadienne de l'education, 51-65. https://doi.org/10.2307/1495395 
Ross, J. A. (1998). The antecedents and consequences of teacher efficacy. In J. Brophy (Ed.), Advances in research on teaching (Vol. 7, p. 4974). Greenwich, CT: JAI Press.

Ross, J. A., Cousins, J. B., \& Gadalla, T. (1996). Within-teacher predictors of teacher efficacy. Teaching and Teacher Education, 12(4), 385-400. https://doi.org/10.1016/0742-051X(95)00046-M

Sakar, N., \& Aybek, B. (2016). An investigation of pre-school teachers' attitudes toward critical reasoning and their perceived professional ethics. Çukurova University Journal of Social Sciences Institute, 25(1), 93-108.

Savas, A. C., Bozgeyik, Y., \& Eser, İ. (2014). A Study on the relationship between teacher self efficacy and burnout. European Journal of Educational Research, 3(4), 159-166. https://doi.org/10.12973/eu-jer.3.4.159

Schunk, D. H. (1995). Self-efficacy and education and instruction. In J. E. Maddux (Ed.), Self-efficacy, adaptation, and adjustment: Theory, research, and application (pp. 281-303). New York: Plenum Press. https://doi.org/10.1007/978-1-4419-6868-5_10

Schunk, D. H., \& Pajares, F. (2009). Self-efficacy theory. Handbook of Motivation at School, 35-53.

Shaabani, F., Maktabi, G. H., Yeylagh, M. S., \& Morovati, Z. (2011). The relationship between academic self-efficacy and creativity with critical thinking in university students. J Edu Manag Stud, 1(1), 32-37.

Skaalvik, E. M., \& Skaalvik, S. (2007). Dimensions of teacher self-efficacy and relations with strain factors, perceived collective teacher efficacy, and teacher burnout. Journal of Educational Psychology, 99(3), 611. https://doi.org/10.1037/0022-0663.99.3.611

Skaalvik, E. M., \& Skaalvik, S. (2010). Teacher self-efficacy and teacher burnout: A study of relations. Teaching and Teacher Education, 26(4), 1059-1069. https://doi.org/10.1016/j.tate.2009.11.001

Skaalvik, E. M., \& Skaalvik, S. (2016). Teacher stress and teacher self-efficacy as predictors of engagement, emotional exhaustion, and motivation to leave the teaching profession. Creative Education, 7(13), 1785. https://doi.org/10.4236/ce.2016.713182

Soodak, L. C., \& Podell, D. M. (1996). Teacher efficacy: Toward the understanding of a multi-faceted construct. Teaching and Teacher Education, 12, 401-411. https://doi.org/10.1016/0742-051X(95)00047-N

Sorensen, G., Gupta, P. C., Nagler, E., \& Viswanath, K. (2012). Promoting life skills and preventing tobacco use among low-income Mumbai youth: effects of Salaam Bombay Foundation intervention. Plos one, 7(4), e34982. https://doi.org/10.1371/journal.pone.0034982

Spaeth, M., Weichold, K., Silbereisen, R. K., \& Wiesner, M. (2010). Examining the differential effectiveness of a life skills program (IPSY) on alcohol use trajectories in early adolescence. Journal of Consulting and Clinical Psychology, 78(3), 334. https://doi.org/10.1037/a0019550

Tschannen-Moran, M., \& Hoy, A. W. (2007). The differential antecedents of self-efficacy beliefs of novice and experienced teachers. Teaching and Teacher Education, 23(6), 944-956. https://doi.org/10.1016/j.tate.2006.05.003

Tschannen-Moran, M., \& Woolfolk Hoy, A. (2002). The influence of resources and support on teachers' efficacy beliefs. Paper presented at the annual meeting of the American Educational Research Association, New Orleans.

Tschannen-Moran, M., \& Woolfolk Hoy, A.W. (2001). Teacher efficacy: Capturing an elusive construct. Teaching and Teacher Education, 17(7), 783-805. https://doi.org/10.1016/S0742-051X(01)00036-1

Türkoglu, M. E., Cansoy, R., \& Parlar, H. (2017). Examining Relationship between teachers' Self-efficacy and job satisfaction. Universal Journal of Educational Research, 5(5), 765-772. https://doi.org/10.13189/ujer.2017.050509

Ümmet, D., \& Demirci, G. (2017). The effect of a group counseling workshop within life skills training on the well-being of secondary school students. Journal of Educational Sciences, 45(45), 153-170.

UNICEF (2012). 2012 Global: Global Evaluation of Life Skills Education Programmes. Retrieved from https://www.unicef.org/evaldatabase/index_66242.html

Watters, J. J., \& Ginns, I. S. (2000). Developing motivation to teach elementary science: Effect of collaborative and authentic learning practices in preservice education. Journal of Science Teacher Education, 11(4), 301-321. https://doi.org/10.1023/A:1009429131064 
Wenner, G. (2001). Science and mathematics efficacy beliefs held by practicing and prospective teachers: A 5-year perspective. Journal of Science Education and Technology, 10(2), 181-187. https://doi.org/10.1023/A:1009425331964

Wheatley, K. F. (2005). The case for reconceptualizing teacher efficacy research. Teaching and Teacher Education, 21, 747-766. https://doi.org/10.1016/j.tate.2005.05.009

Woolfolk Hoy, A. (2000). Educational psychology in teacher education. Educational Psychologist, 35(4), 257-270. https://doi.org/10.1207/S15326985EP3504_04

Woolfolk Hoy, A., \& Davis, H. A. (2006). Teacher self-efficacy and its influence on the achievement of adolescents. Self-efficacy Beliefs of Adolescents, 5, 307-337.

Woolfolk, A. E., Rosoff, B., \& Hoy, W. K. (1990). Teachers' sense of efficacy and their beliefs about managing students. Teaching and Teacher Education, 6(2), 137-148. https://doi.org/10.1016/0742-051X(90)90031-Y

World Heath Organisation (WHO). (1997). Life skills education for children and adolescents in schools: Introduction and guidelines to facilitate the development and implementation of life skills programmes. Geneva, Switzerland: WHO Programme on Mental Health

Yıldız, L., Zırhlıŏlu, G., Yalçınkaya, M., \& Güven, Ş. (2011). Physical Education Teacher Candidates' Skills in Creativity and Problem-Solving. 7th National Physical Education and Sports Teacher Congress VAN/YYU Journal of Faculty of Education Special Edition, 18-36.

Zimmerman, B. J., \& Cleary, T. J. (2006). Adolescents' development of personal agency. The role of self-efficacy beliefs and self-regulatory skills. In F. Pajares \& T. Urdan (Eds.), Self-efficacy beliefs of adolescents (pp. 45-69). Greenwich, CT: Information Age.

Zollinger, T. W., Saywell, R. M., Muegge, C. M., Wooldridge, J. S., Cummings, S. F., \& Caine, V. A. (2003). Impact of the life skills training curriculum on middle school students tobacco use in Marion County, Indiana, 1997-2000. Journal of School Health, 73(9), 338-346. https://doi.org/10.1111/j.1746-1561.2003.tb04190.x

\section{Copyrights}

Copyright for this article is retained by the author, with first publication rights granted to the journal.

This is an open-access article distributed under the terms and conditions of the Creative Commons Attribution license (http://creativecommons.org/licenses/by/4.0/). 